\title{
Progress of preventing mother-to-child transmission of HIV at primary healthcare facilities and district hospitals in three South African provinces
}

\author{
Ashraf Grimwood, Geoffrey Fatti, Eula Mothibi, Brian Eley, Debra Jackson
}

Improving national prevention of mother-to-child transmission (PMTCT) services in South Africa has been challenging. PMTCT outcomes were analysed at 58 primary- and secondary-level antenatal facilities across seven high HIV burden sub-districts in three provinces, over an 18-month period during which new South African PMTCT clinical guidelines were implemented and a nurse quality mentor programme was expanded. Early infant HIV DNA polymerase chain reaction test positivity reduced by $75.2 \%$ from
9.7\% (95\% confidence interval (CI) $8.1-11.5 \%$ ) to $2.4 \%$ (95\% CI $1.9-3.1 \%)(p<0.0005)$. HIV test positivity at 18 months of age decreased by $64.5 \%$ from $10.7 \%$ (95\% CI $7.2-15.1 \%)$ to $3.8 \%$ (95\% CI 2.4 - 5.6\%) $(p<0.0005)$. PMTCT outcomes have improved substantially at these facilities.

S Afr Med J 2012;102:81-83.
Since the introduction of prevention of mother-to-child-transmission (PMTCT) strategies, vertical transmission of HIV has declined in low- and middle-income countries over 20 years from 20 - 40\% to $2.8 \%$ in the best-case scenarios. ${ }^{1}$ In wealthy countries, transmission rates are below $2 \%{ }^{2,3}$ In South Africa, the revised clinical guidelines introduced in 2010 included starting dual zidovudine/nevirapine prophylaxis commencing from 14 weeks' gestation or lifelong antiretroviral treatment (ART) for pregnant women with World Health Organization stage III or IV HIV disease and/or CD4 cell counts below 350 cells $/ \mu l .{ }^{4}$ However, improving South African PMTCT outcomes has been challenging owing to inadequate coverage and sub-optimal implementation of PMTCT programmes. ${ }^{5,6}$

Kheth'Impilo (KI) is a non-governmental organisation supporting South African Department of Health HIV care facilities. KI provides health worker and health system strengthening (including HIV and TB integration, infrastructure support and data collection systems). Nurse quality mentors (QMs), whose key role is to assist facilities to reach the HIV and AIDS National Strategic Plan PMTCT goals, have recently been introduced.

To evaluate progress in PMTCT services over an 18-month period during which the QM programme was scaled up, PMTCT outcomes were analysed at $58 \mathrm{KI}$-supported primary and secondary level antenatal services, across seven high HIV burden sub-districts in three South African provinces (KwaZulu-Natal, Mpumalanga and the Eastern Cape).

\section{Methods}

QMs are professional nurses experienced in maternal, newborn and child health. They focus on quality improvement of PMTCT

Kheth'Impilo AIDS free living, Cape Town

Ashraf Grimwood, MB ChB, MPH

Geoffrey Fatti, MB ChB, MPH

Eula Mothibi, MB ChB, FCP, Dip HIV Man

Paediatric Infectious Diseases Unit, Red Cross War Memorial Children's Hospital, and Department of Paediatrics and Child Health, University of Cape Town Brian Eley, MB ChB, BSc (Hons), FCPaed

School of Public Health, University of the Western Cape, Cape Town Debra Jackson, RNC, MPH, DSc services through a process of mentoring and support of antenatal clinic nurses. KI's QMs support several antenatal care sites within a sub-district to improve quality of care, including basic antenatal care, family planning, integrated management of childhood illness and the Expanded Programme for Immunization. Mentorship involves identifying gaps in service delivery, assisting with developing solutions, improving patient management, improving patient flow, and ensuring that good-quality data are collected. Data registers are developed where they do not exist.

A KI community-support services programme for pregnant women and mother-infant pairs linked to health services, comprising patient advocates, site facilitators and community co-ordinators, provides adherence and psychosocial support. The programme encourages early antenatal booking, treatment adherence, HIV testing of household members, and HIV DNA polymerase chain reaction (PCR) tests for infants 6 weeks after birth, 6 weeks after weaning, and at 18 months of age.

All pregnant women attending antenatal facilities supported by KI between October 2009 and March 2011 were included, during which time the number of supported sites increased from 14 to 58 . Routine facility data according to the data elements in the PMTCT register were collected and aggregated monthly at facility level, forming part of the District Health Information System. Data quality is checked by QMs to ensure accuracy, and gaps identified are corrected. Crosssectional data from six consecutive quarters were analysed. Primary outcomes were positivity rates for PCR tests at 6 weeks of age and HIV antibody tests at 18 months of age. Linear trend in outcomes was assessed using the Cochrane-Armitage test. Existing electronic data from routine monitoring of patients (involving aggregated patient counts) were analysed for this report. No procedures were performed on patients in addition to those performed routinely. Patient-identifying data were not captured electronically.

\section{Results}

As the number of KI-supported sites increased during the study period, the number of women booking at supported sites increased from 5104 to 9789 per quarter (Table I). Between Q1 2010 and Q1 2011, it was evident that increasing proportions of women were on ART at booking, rising from $3.6 \%$ to $5.4 \%$ among all women $(p<0.0005)$, and from $30.9 \%$ to $37.8 \%$ among known HIV-positive women $(p=0.024)$. From Q1 2010 onwards, almost $100 \%$ of women with unknown HIV status had an HIV test, up from 83\% in Q4 2009. A decreasing proportion of HIV-positive 
Table I. Maternal and infant PMTCT outcomes over six consecutive quarters at facilities supported by Kheth'Impilo

\begin{tabular}{|c|c|c|c|c|c|c|c|}
\hline & Q4 2009 & Q1 2010 & Q2 2010 & Q3 2010 & Q4 2010 & Q1 2011 & $p$-trend ${ }^{*}$ \\
\hline Attended first ANC $(N)$ & 5104 & 6445 & 7338 & 6861 & 9098 & 9789 & \\
\hline $\begin{array}{l}\text { Patients known to be HIV positive at } \\
\text { booking }(N(\%))\end{array}$ & $580(11.4)$ & $752(11.7)$ & $785(10.7)$ & $825(12.0)$ & $1297(14.3)$ & $\begin{array}{l}10406 \\
(14.4)\end{array}$ & $<0.0005$ \\
\hline $\begin{array}{l}\text { Known HIV-positive patients on ART at } \\
\text { booking }(N(\%))\end{array}$ & $211(36.4)$ & $232(30.9)$ & $277(35.3)$ & $281(34.1)$ & $475(36.6)$ & $532(37.8)$ & 0.0238 \\
\hline $\begin{array}{l}\text { Proportion ALL patients on ART at booking } \\
(N(\%))\end{array}$ & $211(4.1)$ & $232(3.6)$ & $277(3.8)$ & $281(4.1)$ & $475(5.2)$ & $532(5.4)$ & $<0.0005$ \\
\hline $\begin{array}{l}\text { Estimated HIV-positive mothers not } \\
\text { knowing HIV status at booking }(N(\%))\end{array}$ & $1423(72.2)$ & $2042(73.1)$ & $2168(75.7)$ & $2029(73.6)$ & $2449(66.9)$ & $2559(66.1)$ & $<0.0005$ \\
\hline Tested for HIV at booking $(N)$ & 3742 & 5817 & 6580 & 6267 & 7722 & 8469 & \\
\hline $\begin{array}{l}\text { Patients not known to be HIV positive, HIV } \\
\text { tested at booking }(\%)^{\dagger}\end{array}$ & 82.7 & 102 & 100.4 & 103.8 & 99.0 & $101 \%$ & $<0.0005$ \\
\hline $\begin{array}{l}\text { Patients HIV tested at booking testing HIV } \\
\text { positive }(N(\%))\end{array}$ & $1392(37.2)$ & $2042(35.1)$ & $2080(31.6)$ & $1930(30.8)$ & $2361(30.6)$ & $2468(29.1)$ & $<0.0005$ \\
\hline $\begin{array}{l}\text { Patients retested at } 32 \text { weeks' gestation }(n / N \\
(\%))^{\ddagger}\end{array}$ & $\begin{array}{l}801 / 3132 \\
(25.6)\end{array}$ & $\begin{array}{l}\text { Indicator } \\
\text { dropped for } \\
\text { this Q }\end{array}$ & $\begin{array}{l}1784 / 4473 \\
(39.9)\end{array}$ & $\begin{array}{l}1448 / 4 \\
106(35.3)\end{array}$ & $\begin{array}{l}1987 / 5440 \\
(36.5)\end{array}$ & $\begin{array}{l}2734 / 5915 \\
(46.2)\end{array}$ & $<0.0005$ \\
\hline Tested HIV positive at 32 weeks ( $N(\%))$ & $31(3.9)$ & - & $88(4.9)$ & $99(6.8)$ & $88(4.4)$ & $91(3.3)$ & \\
\hline $\begin{array}{l}\text { Estimated HIV-positive patients at delivery } \\
(N(\%))\end{array}$ & $2003(39.2)$ & $2794(43.4)$ & $2953(40.2)$ & $2854(41.6)$ & $3746(41.2)$ & $3965(40.5)$ & 0.74 \\
\hline Provided with CD4 testing $(N)$ & 1582 & 2327 & 2248 & 2123 & 2538 & 2849 & \\
\hline $\begin{array}{l}\text { HIV-positive patients (not on ART) provided } \\
\text { with CD4 test }(\%)^{\varsigma}\end{array}$ & 88.3 & 90.8 & 84 & 82.5 & 77.6 & 83 & 0.0011 \\
\hline $\begin{array}{l}\text { Eligible patients (estimated) received ZDV/ } \\
\text { NVP (dual therapy) at delivery }(n / N(\%))\end{array}$ & $\begin{array}{l}1384 / 1455 \\
(95.1)\end{array}$ & $\begin{array}{l}2000 / 2194 \\
(91.2)\end{array}$ & $\begin{array}{l}2063 / 1943 \\
(\geq 100)\end{array}$ & $\begin{array}{l}2306 / 1993 \\
(\geq 100)\end{array}$ & $\begin{array}{l}2672 / 2454 \\
(\geq 100)\end{array}$ & $\begin{array}{l}2658 / 2576 \\
(\geq 100)\end{array}$ & \\
\hline $\begin{array}{l}\text { Newly initiated on triple ART (not already } \\
\text { on ART) at delivery }(N)\end{array}$ & $337(16.8)$ & $368(13.2)$ & $733(24.8)$ & $580(20.3)$ & $817(21.8)$ & $857(21.6)$ & $<0.0005$ \\
\hline $\begin{array}{l}\text { Estimated HIV-positive patients on triple } \\
\text { ART at delivery (\%) }\end{array}$ & 27.3 & 21.5 & 34.2 & 30.1 & 34.5 & 35.0 & $<0.0005$ \\
\hline \multicolumn{8}{|l|}{ Infant details } \\
\hline HIV PCR tests at 6 weeks $(N)$ & 1255 & 1706 & 2102 & 2120 & 2480 & 2613 & \\
\hline Tested HIV positive (PCR) $(N(\%))$ & $122(9.7)$ & $68(4.0)$ & $83(3.9)$ & $54(2.5)$ & $77(3.1)$ & $63(2.4)$ & $<0.0005$ \\
\hline HIV antibody tested (at 18 months, ELISA) $(N)$ & 262 & 343 & 409 & 347 & 474 & 637 & \\
\hline Tested HIV positive (18 months) $(N(\%))$ & $28(10.7)$ & $37(10.8)$ & $35(8.6)$ & $29(8.4)$ & $29(6.1)$ & $24(3.8)$ & $<0.0005$ \\
\hline 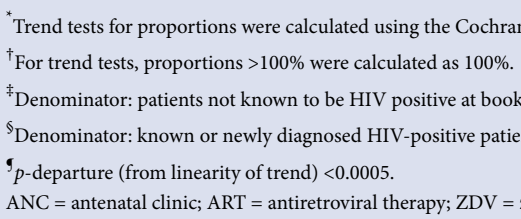 & $\begin{array}{l}\text { e-Armitage chi-squ } \\
\text { ing less patients tes } \\
\text { tts not already on } A\end{array}$ & $\begin{array}{l}\text { ing HIV positive a } \\
\text { RT. }\end{array}$ & booking. & - & - & sorbent assay. & \\
\hline
\end{tabular}

women did not know their status at booking (from $72.2 \%$ to $66.1 \% ; p<0.0005)$, and the proportion of women retested for HIV at 32 weeks' gestation increased from $25.6 \%$ to $46.2 \%$ ( $p<0.0005)$. Despite the booking HIV test positivity rate decreasing from $37.2 \%$ to $29.1 \%$, the estimated overall proportion of women who were HIV positive at delivery remained around $40 \%(p=0.74)$. An increasing proportion of newly diagnosed HIV-positive women started triple ART (from $16.8 \%$ to $21.6 \%$; $p<0.0005$ ), due to the change in guidelines to initiate triple ART at higher CD4 cell counts.
There was a substantial (75.2\%) reduction in early PCR test positivity from $9.7 \%(95 \%$ CI $8.1-11.5 \%)$ to $2.4 \%$ (95\% CI 1.9 $3.1 \%)$ over the study period $(p<0.0005)$. The estimated proportion of missing PCR results ranged between $0 \%$ and $14 \%$ per quarter. A $64.5 \%$ reduction in 18 -month HIV test positivity was found, declining from $10.7 \%$ (95\% CI $7.2-15.1 \%$ ) to $3.8 \%$ (95\% CI $2.4-5.6 \%)(p<0.0005)$. The relative proportion of children receiving 18-month HIV tests versus 6-week PCR tests was low, but improved during the last quarter from $19.1 \%$ to $24.4 \%$. 


\section{Discussion}

PMTCT outcomes improved substantially during a period in which new PMTCT guidelines were implemented at sites receiving support from nurse QMs and community-based adherence supporters. Substantial reductions in early PCR and 18-month HIV test positivity rates are encouraging compared with previous outcomes in resourcelimited settings. ${ }^{3,7}$ The high rates of HIV testing, antiretroviral treatment and prophylaxis uptake, and an almost twofold increase of the 32-week gestation HIV retest rate, indicate a strengthening health system.

The national ART programme demonstrates increased access through more women being on triple ART at booking, and increasing numbers of pregnant women starting triple ART. This contributes to maintaining the high antenatal prevalence of HIV due to increased survival of women on ART. The national HIV counselling and testing campaign shows greater impact, as more HIV-positive women know their status at booking; however, two-thirds still do not know their status when booking.

Many challenges to South African PMTCT programmes remain. Pregnant women need to book earlier, and facilities should accommodate them without turning them away for later appointments. Women may seroconvert during late pregnancy or breastfeeding, potentially resulting in vertical transmission. Retesting of HIV-negative women through their antenatal phase to the end of breastfeeding is required. This may be done through community outreach by community care workers and can include testing of household members. CD4 cell testing of mothers and early PCR testing in infants need to be increased, which may be facilitated by point of care CD4 and PCR technology. Longer-term outcomes of children are poorly reported in this and other South African studies owing to difficulties in follow-up of mothers and children. ${ }^{8}$ This is best addressed through community care workers who understand PMTCT and support mothers through their pregnancy to after weaning, ensuring regular testing of children at local clinics. Children should also receive HIV testing at 18 months regardless of HIV exposure history. Mixed feeding is a challenge, as exclusive feeding has become stigmatised as an indicator of HIV infection. Exclusive breastfeeding should be clearly promoted as the ideal norm for all breastfeeding mothers as per government guidelines.

Improved data collection systems for accurate routine reporting, and further health systems implementation research, are needed as health services strive toward reaching UNAIDS' vision of zero HIV transmission and HIV-related maternal mortality by 2015 . To achieve this, however, adult HIV prevention efforts with routine HIV counselling and testing continue to be imperative.

Sources of support: President's Emergency Plan for AIDS Relief. Conflicts of interest: Nil to declare.

\section{References}

1. Family Health International. Preventing mother-to-child transmission of HIV: A strategic framework. 2004. http://www.fhi.org/NR/rdonlyres/eau635cfyvj45mvwlkmjwrqoimu qs6wgorcb2szmke7ijfsrhqrsgzkgiai7rpq2wki5pcszm4xueg/MTCTStrategyFinal.pdf (accessed 15 June 2011).

2. Siegfried N, van der Merwe L, Brocklehurst P, Sint TT. Antiretrovirals for reducing the risk of motherto-child transmission of HIV infection. Cochrane Database of Systematic Reviews. CD003510. 2011. http://www.mrw.interscience.wiley.com/cochrane/clsysrev/articles/CD003510/frame.html (accessed 1 http://www.m

August 2011)

3. Paintsil E, Andiman WA. Update on successes and challenges regarding mother-to-child transmission of HIV. Curr Opin Pediatr 2009;21(1):94-101.

4. South African National Department of Health and South African National AIDS Council. Clinical guidelines: prevention of mother-to-child transmission. 2010. http://www.fidssa.co.za/images/ PMTCT_Guidelines.pdf (accessed 11 April 2011).

5. Chopra M, Daviaud E, Pattinson R, Fonn S, Lawn JE. Saving the lives of South Africa’s mothers, babies, and children: can the health system deliver? Lancet 2009;374(9692):835-846. http://www.thelancet. com/journals/lancet/article/PIIS0140-6736(09)61123-5/abstract (accessed 10 February 2011).

6. Sprague C, Chersich M, Black V. Health system weaknesses constrain access to PMTCT and maternal HIV services in South Africa: a qualitative enquiry. AIDS Research and Therapy 2011;8(1):10. http:// www.aidsrestherapy.com/content/8/1/10 (accessed 10 July 2011)

7. Coetzee D, Hilderbrand K, Boulle A, Draper B, Abdullah F, Goemaere E. Effectiveness of the firs district-wide programme for the prevention of mother-to-child transmission of HIV in South Africa. Bull World Health Organ 2005;83:489-494. http://www.who.int/bulletin/volumes/83/7/ Africa. Bull World Health Organ 2005;83:489-494. http://ww
coetzeeabstract0705/en/index.html (accessed 16 November 2009).

coetzeeabstract0705/en/index.html (accessed 16 November 2009). of HIV in a resource-limited setting -lessons from a South African programme. S Afr Med 2011;101:651-654. http://samj.org.za/index.php/samj/article/view/4712/3410 (accessed 15 Septembe 2011)

Accepted 12 December 2011. 